\title{
Rejoinder to Miriam Ben-Peretz
}

\author{
SIMONE A. SCHWEBER \\ University of Wisconsin-Madison \\ Madison, Wisconsin, USA
}

I would like to thank Miriam Ben-Peretz for her thorough and thoughtprovoking response to my article, "Simulating Survival." Especially in light of her personal experiences as a refugee from Hitler's Germany, I was impressed by her ability to judge my narrative with even-handed precision and to render clear-headed critiques. I don't mean to imply that eyewitnesses to events are unreliable judges of them, only that the gulf between lived history and learned history ${ }^{1}$ is vast and that the emotional stakes in the representation of the former seem to me necessarily to trump those involved in the latter. It must be a strange thing, indeed, to read about a simulation, not of abstract historical events but of personally lived history. That said, I am not at all surprised that Ben-Peretz reaches conclusions about the simulation's moral weight that are different from my own. In this rejoinder, I discuss a few of the excellent points she raises, attempting to illuminate the convergence and disparities in our visions of Ms. Bess's class. My rejoinder primarily addresses two of the sections in Ben-Peretz's essay, "Interactive Teaching" and "Why Teach the Holocaust?"

\section{ON THE POWER AND LIMITS OF "INTERACTIVE EDUCATION"}

To start, it is worth reiterating Ben-Peretz's point about the construction of cases. When she writes that "the article focuses mainly on the simulation and this might lead to a misreading of the events in Ms. Bess's class," she highlights the boundaries of the case as I've drawn them. Were I to have written about the course as a whole rather than focusing on its simulation component only, a very different characterization of Ms. Bess's practice would have emerged. Interestingly, the course as a whole might have satisfied Ben-Peretz's yearning for a more "interactive" engagement of students. Although as Ben-Peretz points out, "little space was provided for students to raise their own questions, to search for diverse sources of knowledge, and to create and share with others their constructed understanding[s]" within the simulation, Ms. Bess did provide such opportunities in the other strands of her course, the units that I did not describe in 
any depth in the article. In other words, Ms. Bess was not adverse to constructivist teaching per se; I suspect that she simply didn't consider such methods appropriate for the Holocaust simulation.

The simulation, after all, was meant to mimic the experience of living (or not) as victims targeted under Nazi fascism, the experience of having behavioral options radically narrowed by constellations of historical circumstance, specifically by the constraints of dictatorial rule. The purposes of the simulation would thus seem to be ill served by a student-centered, project-based or fully "negotiated" curriculum, wherein students "play a role in determining the content, scope, and mode of learning." The very thing being simulated in this case disallows that kind of pedagogy to prevail. Put differently, a pedagogical form that promotes a democratic ethos or at least some measure of self-direction seems ill suited to the purpose of teaching about brute victimization under totalitarianism.

Beyond this issue of pedagogical-content fit, I suppose I disagree with Ben-Peretz's general implication that only "interactive" education of the type she champions can be truly "transformative." Philip Jackson, author of the seminal work to which Ben-Peretz refers, describes two "traditions," which he identifies as the mimetic and transformative (1986). Although consistently cautioning that his model encompasses exceptions, Jackson nonetheless associates the mimetic primarily with informational transmission or knowledge acquisition and the transformative mainly with character development or the attainment of wisdom. Thus the two traditions not only carry with them preferred pedagogical forms but are more disposed to particular disciplinary domains-science or math for the mimetic, English and social studies for the transformative. Ben-Peretz, in her critique, implies that the simulation tended toward the mimetic rather than the transformative, referring to Ms. Bess's practice as "factual teaching," "totally preplanned by the teacher," whereby the students were not "provided with opportunities [to] shape their own learning path[s]."

As I see it, Ben-Peretz, following Jackson, here conflates some of the simulation's dimensions that seem worth teasing apart while bifurcating others that deserve to be fused. Ben-Peretz seems to equate the process with the outcomes, assuming that mimetic instruction yields mimetic ingestion and that transformational teaching wields transformational impact (to overuse Jackson's terminology). Ben-Peretz seems to claim that because Ms. Bess's simulation format was mimetic - set up for students rather than coconstructed with them-that the students' learning was likewise mimetictransmitted or additive rather than architecturally transformational. I'm not sure that I would argue Ms. Bess's simulation was mimetic (in Jackson's sense) in the first place, but while I understand Ben-Peretz's reasons for thinking so, I nonetheless consider its impact to have been transformative in the lives of her students, that is, I consider the simulation experience indeed to have "modif[ied] character, instill[ed] values, shape[d] attitudes, [and] generate[d] new interests," even if (or more decidedly, because) Ms. 
Bess set the educational agenda. In short, as I see it, there are multiple paths-interactive and noninteractive ones-that can lead to transformational learning, specifically transformational learning about atrocity.

Jackson's typology itself bears the problematic polarization of the informational and the moral, implying that the two are not ineluctably conjoined. Of course in all fairness to the author, later works in his corpus decry this binary (most notably, The Moral Life of Schools, Jackson, Boostrom, \& Hansen, 1993). But the central fallacy that only particular pedagogical arrangements are conducive to moral learning nonetheless seems to underpin Ben-Peretz's claims. My conviction, by contrast, is that all pedagogical-content systems have the power to inform morally and transform informationally, if done well, just as all have the power to fall flat, if executed badly. I do not mean to suggest that certain pedagogical arrangements don't have higher rates of return (so to speak), ${ }^{2}$ but that all, under particular conditions, bear the potential to wield tremendous effects- "transformative" effects—on students. One example might help illustrate the point.

Ms. Bess's simulation was originally part of a larger study ${ }^{3}$ based on four cases, all of which included teachers who came highly recommended for innovative teaching in public high schools with diverse student bodies. In another of the cases, the teacher lectured almost exclusively (perhaps the least "interactive" teaching technology available). And yet, the content of the lectures had the power to "transform," and, I think, to transform profoundly. At the time the study was conducted, Vince was a ninth-grade Indian-American student whose family had just moved to California from Fiji. He worked at a shipping yard after school to earn money. After hearing a well-crafted lecture on the Kitty Genovese story, Milgram's shock experiments, Ash's experiments on conformity, and Zimbardo's prison experiments-the teacher's attempts to explain perpetrators' actions during the Holocaust-Vince was moved to imagine the world and to consider his own behavior within it differently. As he reported to me:

[When my teacher] was giving those examples on that research that they did up in Stanford, I think, or something like that ${ }^{4} \ldots$ well, that affected me in like, if somebody tells me something to do, I'm going to think twice now to make sure I'm doing the right thing or not, if I'm hurting somebody or if I'm not or something like that.

Like a while back, a couple of my friends, they were sort of like messing around. They were like capping on each other and stuff like that, and I was thinking, "should I get involved?" "cause everybody's all doing it. Should I get involved or will this like lead to something else if I say something that might offend somebody? So, I was like, no, I don't think I'll get involved. (Int\#2, 1/17/97)

Vince explained to me, too, that he had decided from that point on not to brandish insults under any conditions. I don't know if this shift in Vince's behavior was long lasting or short lived, generalized or isolated, actual or 
simply reported; to me his proclamation was dramatic enough regardless. (It is worth mentioning, I suppose, that I'm writing this rejoinder in the wake of news that a group of kids beat a man to death in Milwaukee, having first pressured a 10-year-old to throw an egg at him.) My point in mentioning Vince is simply to underscore the importance of neither severing the moral from the informational nor of mistaking a pedagogical preference for its potential impacts.

\section{ON VIEWS FROM WHICH TO TEACH ABOUT THE HOLOCAUST}

In the section, "Why Teach about the Holocaust?" Ben-Peretz lays out what I consider to be her weightier objections to the simulation, basing them in part on a comparison she draws between the situations in Israel and the United States. "It is interesting to note," Ben-Peretz writes, "that in different contexts and cultures we find similar attempts to make the unthinkable events of the Holocaust emotionally accessible to students." Following Schatzker (1982), Ben-Peretz summarizes three modes of education that characterized Israel's educational history of grappling with Holocaust memory: the first is primarily commemorative; the second is more "instructional," what Schatzker describes as utilizing "sober rather than sacral-ritual[istic]" teaching methods; the third Schatzker identifies as "existential," by which he seems to mean that it forges a connection in students with the existential dilemmas posed by truly horrific conditions. BenPeretz suggests that Ms. Bess's simulation fits within Schatzker's third mode of Holocaust education in that it encourages students to "identify with the traumatic experiences of the Holocaust," serving thus as a means for catharsis. My arguments with Ben-Peretz's (and Schatzker's) positions here are multiple, but they originate in an overarching conceptual difference over the nature of the Holocaust as an historical event.

The difference rests on a debate that punctuated what might be considered the "early period" of Holocaust historiography and that continues today unabated. Centered on whether the Holocaust is unique or universal-and polarized as such-the debate carries with it awkward ramifications. Inga Clendinnen (1999) encapsulates the debate with marvelous succinctness:

The continuing argument between scholars both secular and religious as to whether the Holocaust constitutes an event unique in European (even in world) history usefully focuses attention on particular characteristics of the events, but the discussion easily leaks in one of two directions; [Those who argue for its uniqueness point the discussion in the direction of] either tempting us to regard the Holocaust as no more than the worst pogrom in Jewish history, or to declare it unique in human history because it is unique in Jewish history. Elie Wiesel, perhaps the most widely read writer on the Holocaust, assumes the natural dominance of the metaphysical over the historical [when he writes]: "The universality of the 
Holocaust must be realized in its uniqueness. Remove the Jews from the Holocaust, and the Event loses its mystery." (Clendinnen, 1999, p. 11)

Like Elie Wiesel, those who argue for the uniqueness of the Holocaust tend to capitalize it as an "Event," considering it at some level "mysterious," "unthinkable," or fundamentally "incomprehensible" and, in a sense (indeed in different senses), "outside of history." Like Elie Wiesel, too, they consider both its place in Jewish history and the central importance of Jews to its history as foundational. The Holocaust was unique in history, uniquely Jewish, and unimaginable in the uniqueness of its horrors. Wiesel, Schatzker, Ben-Peretz, and Totten are all adherents to this way of thinking, to greater or lesser degrees. Thus Schatzker, as Ben-Peretz quotes him, bemoans the second type of Holocaust education, that type that is universalistic, in that "there is a danger that [the Holocaust] will be dwarfed, diminished and will lose its unique significance ... instead of making students sensitive to the abnormalities of the Holocaust."

I'm in the paradoxical position of rejecting the binary posed by this debate and simultaneously locating myself along its contested continuum. (Indeed most of those who locate their orientations near the more "universalistic" pole tend to decry the debate itself.) Within this school of thought, all historical events are both unique and universal: unique in the constellations of events that produce, perpetuate, and constitute them, and yet universal in their implications, or at least potentially so. No event lies outside of history nor could it. And all human suffering that is not our own bodily or psychic suffering, so this line of argument goes, is as indecipherable and unbreachable to our selves as any other, whether en masse or individual, whether mass produced with an assembly-line efficiency (as in the concentration camps) or whether whimsically effected by the randomness of chance (as in the loss of a child to a freak accident). To apprehend the suffering of another, whatever its form, is always and unavoidably constrained by impossibilities, not uniquely so when considering those who lived through or died during the Holocaust.

Along with the historians Inga Clendinnen, Michael Marrus, and Yehudah Bauer, ${ }^{5}$ as well as the Nobel laureate (and survivor) Imre Kertész ${ }^{6}$ I find the implications of the unique stance knotty. As Geoff Eley (1982) writes, "To insist upon the uniqueness of the event is a short step to insisting on the exclusiveness of interpretation which asserts an empathetic privilege and even a Jewish proprietorship in the subject" (1982, p. 6), a situation that is clearly unproductive, at the very least, for the furthering of the discipline. For if the Holocaust is unique and uniquely incomprehensible to all but survivors (or Jews), as Clendinnen elucidates, "the implication is that the only possible and proper stance for the observer is one of awed incomprehension" (1999, p. 21), and:

If that is true, it is a threat to us all, as abominations seem to multiply, as our reservoirs of shared metaphors for the systematic and serious discussion of human affairs 
beyond the narrowly personal are running dry. It is a particular threat to historians, who are committed to the quixotic notion that the human actions of the past are sufficiently amenable to retrieval, analysis and interpretation to generate useable truths for the present, and that no part of the human record can be declared off-limits. (1999, p. 21)

It seems to me that this stance is also a particular threat to educators who are committed to the quixotic notion that humans can learn from the past, though what it is we learn and what we do with those "lessons" may well be vexed. ${ }^{7}$

It is this divide, I believe, that helps explain the differences between Ben-Peretz's and my assessment of Ms. Bess's failure to teach the history of anti-Semitism as an integral part of the simulation. As I see it, Ms. Bess's omission was significant, exceedingly so. I consider Ms. Bess, in overlooking the history of anti-Semitism, to have missed a definitive, root cause of the Holocaust, a necessary, if not sufficient, condition for this genocide to have occurred and a key explanatory framework for understanding the Holocaust. And yet, from my perspective, the omission occurred in an otherwise informationally rich unit, one that endowed students with a complex sense of historical context, if not this important web of historical meaning. For Ben-Peretz, however, the omission is tantamount to denying students "knowledge about the historical context" in its entirety. For her, Ms. Bess's neglecting to teach the history of anti-Semitism means that "the Holocaust loses its historical meaning as an event." Based in differing conceptions of the uniqueness or universality of the Holocaust, our difference here seems to be over the moral weight of the oversight, not over its educational import.

It would be easy to essentialize the explanatory differences between BenPeretz and myself and to locate our ideological proclivities within our biographical particularities. Miriam Ben-Peretz is a "Jewish [educator] living among Jews in a Jewish state. ${ }^{8}$ By contrast, I am a white American Jew, one who has grown up firmly planted in the middle class, taking for granted the great freedoms of American universalism (since I experienced none of the curses of its myths). The trap of ascribing our positions in this debate to these elements of our biographies is betrayed, though, by the numerous Israeli universalists of Ben-Peretz's generation and the many American Jews (and non-Jews) who argue for the uniqueness of the Holocaust regardless of generation.

To return for a moment to Schatzker's typology, I find Ben-Peretz's application of it to a U.S. school-as a rhetorical move-especially flawed. On the one hand, this makes sense given my expressed animosity for the unique-universal debate on which Schatzker's classification system rests in the first place. On the other hand, though, it ought to be recalled that Schatzker's system as a whole assumes an Israeli context, one where identification with Holocaust victimization may have been a stretch of the imagination for students in past generations ${ }^{9}$ but where identification with Jews 
as such never was. To "simulate survival" in an Israeli context, then, I think of as being a different thing entirely from its counterpart in the United States, even if the strategies across contexts may indeed be "similar."

Regardless of these arguments, Ben-Peretz may be pleased to learn that Ms. Bess has modified her simulation in the years since the one I observed, and many of the alterations coincidentally seem tailored to Ben-Peretz's critique. For example, Ms. Bess now has students seek out the testimonies of Holocaust survivors whose experiences in some way "model" (so to speak) what the students' characters simulate, thereby, I suspect, deepening their understandings of their historical counterparts and widening their empathic bridges. Ms. Bess also has students keep a journal of their experience in the simulation, encouraging them to reflect in a more consistent fashion on the moral conundrums they face both as characters in the simulation and as students simulating. She has made it a point, moreover, to help students understand the history of anti-Semitism as an integral factor in explaining this atrocity, a development both Ben-Peretz and I can agree is crucially important. In closing, I'd like to thank Ben-Peretz again for her generous remarks and to communicate my fundamental respect for her positions despite my disagreements.

\section{NOTES}

1. Sam Wineburg drew the distinction between "lived memory and learned memory" (2001, p. 234) in his research on parents' and children's understandings of the Vietnam War, gracefully dissecting not only the emotional disjunctures between generations, but their accompanying assumptions about the historical terrain.

2. Generally speaking, I am persuaded by the argument Katherine Simon (2001) articulates through the ground-breaking research presented in her book, Moral Questions in the Classroom, that indeed discussion of the moral dimensions of curricular content are crucial, difficult to do well and potentially tremendously powerful.

3. This is a shameless promotion. The larger study is being published as a book by Teachers College Press.

4. I suspect that Vince was confusing Stanford University for Yale University, the site of Stanley Milgram's experiments, and simultaneously lumping together all the social-psychological studies he had learned about.

5. For two of most comprehensive and nuanced accounts of this debate, see Michael Marrus's discussion of "The Uniqueness of the Holocaust" in his seminal book, Holocaust in History (1987), or Inga Clendinnen's section, "The Issue of Uniqueness," in her outstanding book, Reading the Holocaust.

6. In his essay, "Who Owns Auschwitz?" Imre Kertész obliquely but clearly proclaims his position within this debate by writing, "I regard as kitsch any 
representation of the Holocaust that is incapable of understanding or unwilling to understand the organic connection between our own deformed mode of life (whether in the private sphere or on the level of 'civilization' as such) and the very possibility of the Holocaust. Here I have in mind those representations that seek to establish the Holocaust once and for all as something foreign to human nature; that seek to drive the Holocaust out of the realm of human experience. I would also use the term kitsch to describe those works where Auschwitz is regarded as simply a matter concerning Germans and Jews, and thereby reduced to something like the fatal incompatibility of two groups; when the political and psychological anatomy of modern totalitarianism more generally is disregarded; when Auschwitz is not seen as a universal experience, but reduced to whatever immediately 'hits the eye"' (p. 270).

7. Another shameless promotion: the last chapter of my forthcoming book deals with the problem of "lessons" to be learned from the Holocaust. For (an already published and well-articulated) stance on the dilemmas involved, see the last chapter of Peter Novick's (1999) book, The Holocaust in American Life.

8. I have adopted the language Yehuda Bauer uses in writing about himself in the introduction to his book, Rethinking the Holocaust: "I am a Jewish historian, living among Jews in a Jewish state; I have to take such preconditioning into account" (2001, p. xi).

9. For a fuller treatment of the complex relationship of Israel's nationalized system of education to the Holocaust, see Tom Segev's accessible (and controversial) (1993) book, The Seventh Million. In my remarks, I don't mean to imply that all Israelis are Jewish; of course they are not.

\section{REFERENGES}

Bauer, Y. 2001. Rethinking the Holocaust. New Haven, CT: Yale University Press.

Clendinnen, I. 1999. Reading the Holocaust. Cambridge: Cambridge University Press. Eley, G. 1982. Holocaust history. London Review of Books March: 3-17.

Jackson, P. W., R. E. Boostrom, and D. T. Hansen. 1993. The moral life of schools. San Francisco, CA: Jossey-Bass Publishers.

Jackson, P. 1986. The practice of teaching. New York: Teachers College Press.

Kertész, I. 2001. Who Owns Auschwitz? Yale Journal of Criticism 14 (1): 267-72.

Marrus, M. 1987. The Holocaust in history. New York: Meridien Books.

Novick, P. 1999. The Holocaust in American life. New York: Houghton Mifflin.

Schatzker, C. 1982. The Holocaust in Israeli education. International Journal of Political Education 5 (1): 75-81.

Segev, T. 1993. The seventh million: The Israelis and the Holocaust. New York: Hill \& Wang.

Simon, K. 2001. Moral issues in the classroom. New Haven CT: Yale University Press.

Totten, S. 2000. Diminishing the complexity and horror of the Holocaust: Using simulations in an attempt to convey historical experiences. Social Education 64 (3): 165-71.

Wineburg, S. 2001. Historical thinking and other unnatural acts: Charting the future of teaching the past. Philadelphia, PA: Temple University Press. 